\title{
Dynamic life-cycle carbon analysis for fast pyrolysis biofuel produced from pine residues: implications of carbon temporal effects
}

Kai Lan ${ }^{1}$, Longwen Ou², Sunkyu Park', Stephen S. Kelley ${ }^{1}$, Prakash Nepal ${ }^{3}$, Hoyoung Kwon ${ }^{2}$, Hao Cai ${ }^{*}$ and Yuan $\mathrm{YaO}^{1,4^{*}}$ (B)

\begin{abstract}
Background: Woody biomass has been considered as a promising feedstock for biofuel production via thermochemical conversion technologies such as fast pyrolysis. Extensive Life Cycle Assessment studies have been completed to evaluate the carbon intensity of woody biomass-derived biofuels via fast pyrolysis. However, most studies assumed that woody biomass such as forest residues is a carbon-neutral feedstock like annual crops, despite a distinctive timeframe it takes to grow woody biomass. Besides, few studies have investigated the impacts of forest dynamics and the temporal effects of carbon on the overall carbon intensity of woody-derived biofuels. This study addressed such gaps by developing a life-cycle carbon analysis framework integrating dynamic modeling for forest and biorefinery systems with a time-based discounted Global Warming Potential (GWP) method developed in this work. The framework analyzed dynamic carbon and energy flows of a supply chain for biofuel production from pine residues via fast pyrolysis.
\end{abstract}

Results: The mean carbon intensity of biofuel given by Monte Carlo simulation across three pine growth cases ranges from 40.8-41.2 $\mathrm{g} \mathrm{CO}_{2} \mathrm{e} \mathrm{MJ}^{-1}$ (static method) to 51.0-65.2 $\mathrm{g} \mathrm{CO}_{2} \mathrm{e} \mathrm{MJ}^{-1}$ (using the time-based discounted GWP method) when combusting biochar for energy recovery. If biochar is utilized as soil amendment, the carbon intensity reduces to 19.0-19.7 $\mathrm{g} \mathrm{CO}_{2} \mathrm{e} \mathrm{MJ}^{-1}$ (static method) and 29.6-43.4 $\mathrm{g} \mathrm{CO}_{2} \mathrm{e} \mathrm{MJ}^{-1}$ in the time-based method. Forest growth and yields (controlled by forest management strategies) show more significant impacts on biofuel carbon intensity when the temporal effect of carbon is taken into consideration. Variation in forest operations and management (e.g., energy consumption of thinning and harvesting), on the other hand, has little impact on the biofuel carbon intensity.

Conclusions: The carbon temporal effect, particularly the time lag of carbon sequestration during pine growth, has direct impacts on the carbon intensity of biofuels produced from pine residues from a stand-level pine growth and management point of view. The carbon implications are also significantly impacted by the assumptions of biochar end-of-life cases and forest management strategies.

Keywords: Life-cycle carbon analysis, Dynamic modeling, Carbon accounting, Biofuel, Fast pyrolysis, Pine residues, Monte Carlo simulation

\footnotetext{
*Correspondence: hcai@anl.gov; y.yao@yale.edu

1 Department of Forest Biomaterials, North Carolina State University, 2820 Faucette Drive, Raleigh, NC 27606, USA

2 Systems Assessment Center, Energy Systems Division, Argonne National Laboratory, 9700 South Cass Avenue, Lemont, IL 60439, USA

Full list of author information is available at the end of the article
}

\section{Background}

Cellulosic biofuel produced from renewable biomass has great potential to enhance energy security while reducing the environmental impacts of the transportation sector [1-3], which accounts for $29 \%$ of the total US emissions original author(s) and the source, provide a link to the Creative Commons licence, and indicate if changes were made. The images or other third party material in this article are included in the article's Creative Commons licence, unless indicated otherwise in a credit line to the material. If material is not included in the article's Creative Commons licence and your intended use is not permitted by statutory regulation or exceeds the permitted use, you will need to obtain permission directly from the copyright holder. To view a copy of this licence, visit http://creativecommons.org/licenses/by/4.0/. The Creative Commons Public Domain Dedication waiver (http://creativeco mmons.org/publicdomain/zero/1.0/) applies to the data made available in this article, unless otherwise stated in a credit line to the data. 
(6457 million metric ton $\mathrm{CO}_{2} \mathrm{e}$ ) in 2017 [4]. The US Renewable Fuel Standard mandates that $44 \%$ of the US total renewable fuel derived from cellulosic biofuels in 2022, and that these cellulosic biofuels achieve at least a $60 \%$ reduction in life-cycle greenhouse gas (GHG) emissions compared to the 2005 petroleum baseline [5]. The potential energy and environmental benefits of cellulosic biofuel, which is critical for decision-making related to biofuel policy, research, development, and commercialization, are often quantified through Life Cycle Assessment (LCA) covering cradle-to-grave stages for biofuel production associated with various feedstocks and conversion technologies [6-26]. Among many conversion technologies, fast pyrolysis has attracted the most attention for its ability to produce a suite of fuel products from a wide variety of biomass feedstocks. Fast pyrolysis is a thermochemical conversion technology that rapidly decomposes organic compounds under temperature between $400-600{ }^{\circ} \mathrm{C}$ in an oxygen-limited atmosphere to create a crude bio-oil that can be further refined into fuel products [27]. Most LCA models have implemented fast pyrolysis processes based on different lignocellulosic feedstocks, including corn stover, switchgrass, miscanthus, and pine residues [15, 16, 28-33].

Forest residues generated in thinning, logging, and wood product manufacturing are one of the most abundant feedstocks in the US. According to the Billion-Ton Study by the US Department of Energy (US DOE) [34], there are potentially $30-108$ million oven dry metric tons of forest residues available each year. This resource is currently underutilized as it is either left on-site or much less commonly burned for energy recovery $[34,35]$. There has been a growing interest in converting forest residues to biofuels to enhance the efficient utilization of forest resources, reduce the risks of forest wildfire, and bring additional revenue to landowners [36-39]. A few studies have conducted LCA for forest residue-derived biofuel and indicated a significant reduction (36-67\%) of life-cycle GHG emissions compared to conventional fuels [10, 14, 15, 32, 33]. Nonetheless, most studies have not assessed the impacts of feedstock variations that are particularly important for woody biomass given the wide diversity of forest types, growing regions, forest management practices, and harvesting alternatives. More importantly, few LCA studies have investigated carbon temporal effects or examined the carbon neutrality assumption for biofuel derived from woody biomass that is generally considered carbon-neutral despite its much longer growth cycle compared to annual crops or perennial biomass. Addressing all these issues is critical to developing sustainable strategies for forest management as the carbon emitted from the decay and the combustion of forest residues, and carbon stored in durable wood products are temporally dynamic and highly driven by forest management strategies that may also influence biofuel production. To quantify the carbon temporal effects, several studies have proposed corresponding Global Warming Potential (GWP) accounting methods and showed the necessity of considering carbon dynamics related to bioenergy products [40-47]. For example, in 2011, Cherubini et al. [40] proposed a method to estimate the GWP of $\mathrm{CO}_{2}$ emissions from biomass combustion based on impulse response functions (IRF) of $\mathrm{CO}_{2}$, and showed that the current static assumption or carbon neutrality assumption should be revised by considering the carbon dynamics in bioenergy system. Levasseur et al. [41] developed a dynamic GWP accounting approach considering the temporal profiles of GHG emissions and applied the method to a GWP comparison between corn ethanol and gasoline. The results displayed that considering the carbon temporal effects is critical for qualifying the goal achievement of reducing GWP by using biofuel instead of fossil fuel [41]. Faraca, Tonini and Astrup [44] quantified the GWP of varied wood waste cascading systems with considering the temporal profile of GHG emissions, and concluded that accounting the temporal effects of GHG emissions was critical for biogenic $\mathrm{CO}_{2}$ and storage [44]. Yang and Chen [45] applied the dynamic GWP accounting method to syngas production by the gasification system from crop residues in China. The results of the dynamic method showed a discounted GWP mitigation benefit from using crop residues compared to the traditional static method [45]. Daystar et al. [46] applied the GWP accounting approach developed by Levasseur et al. [41] to examine the GWP of ethanol production from six lignocellulosic feedstocks under varied time horizons. The results emphasized the importance of GHG emission temporal profiles and analytical time horizons [46]. However, few of these dynamic GWP studies considered the impacts of variations in forest dynamics and forest management scenarios on the GWP results. Several studies included the carbon dynamics of forest systems in carbon analysis and showed the necessity of including carbon temporal profiles of forest growth [48-55], but these studies used other indicators such as carbon payback time. For example, Sterman, Siegel and Rooney-Varga [48] simulated the replacement of wood for coal in electricity generation and tracked the carbon fluxes in forest, atmosphere, and soil. The payback time for the carbon debt was reported to range from 44 to 104 years, depending on forest type and growth. Following the work by Sterman, Siegeland Rooney-Varga [48], Rolls and Forster [51] replicated the model and modified the input parameters to predict the forest carbon uptake and payback time of the carbon debt with considering the uncertainty in forest growth. This 
study showed the payback time largely dependent on the uncertainty of forest growth curves [51]. Jonker, Junginger and Faaij [49] calculated the carbon payback period for wood pellets from softwood forest, taking into consideration the temporal profiles of forest growth under several management scenarios. The results highlighted the impacts of forest growth and yield, carbon replacement factor (i.e., how much fossil carbon is avoided by using 1 metric ton biomass carbon), system boundaries, and the baseline selection, on the carbon payback period [49]. Although these studies included the forest carbon dynamics that mainly affect carbon uptake, they did not include the temporal effects of carbon emissions along the biofuel supply chain on the GWP results.

The overall objective of the study is to conduct a dynamic life-cycle carbon analysis allowing for assessing the impacts of forest dynamics and carbon temporal effects on the life-cycle carbon implications of fast pyrolysis biofuels derived from forest residues, which has not been quantified in the literature reviewed above. By mathematically linking key parameters related to the biorefinery operations and alternative forest management scenarios with Monte Carlo simulation and process-based forest growth simulation, the study includes the dynamic profiles of both carbon emissions and uptake. Furthermore, this study developed a time-based discounted GWP method (100-year analysis timeframe) to incorporate the climate effects of carbon emissions/uptake at different years. The results of the dynamic carbon modeling method were compared to the traditional life-cycle carbon analysis relying on the carbon neutrality assumption to examine the impacts of incorporating carbon dynamics. This study aims to provide critical understandings of carbon dynamics across the forest, biorefinery, and biofuel consumption for the design, planning, and optimization of future biomass-to-biofuel systems.

\section{Results}

\section{Forest growth}

This study explored three growth cases (GC1-3) where different $\mathrm{GC}$ represents varied site productivity and management strategies (see "Methods" for details). In each case, the aboveground biomass yield was simulated using the FASTLOB simulation and the results are shown in Fig. 1 [56]. The simulation results include the aboveground live tree biomass and total pine residues generated from precommercial thinning per ha forest land for 30 years (1 rotation). The breakdown of logs and residues (mean value) for 1 rotation cycle is plotted in Fig. 1 with error bars showing the 5th-95th percentile (P5-P95) range of the Monte Carlo simulation results. The residues in Fig. 1 include all the pine residues from precommercial thinning and logging, 50\%$70 \%$ of which are collectible for biofuel production (see Table 1). Among the three cases, GC2 has the highest $\log$ output (485 metric ton ha ${ }^{-1}$ ), while GC3 has the highest residue output (191 metric ton ha ${ }^{-1}$ ). The reasons are that GC3 has precommercial thinning in year 12 while GC2 has no precommercial thinning and that both GC2 and GC3 have a high site index. GC1 has the lowest outputs for both logs and residues due to the low site index. More temporal details of the LCI data are available in Section "A time-based discounted GWP method for addressing the carbon temporal effect" and Additional file 1: Section "Pine growth and yield".

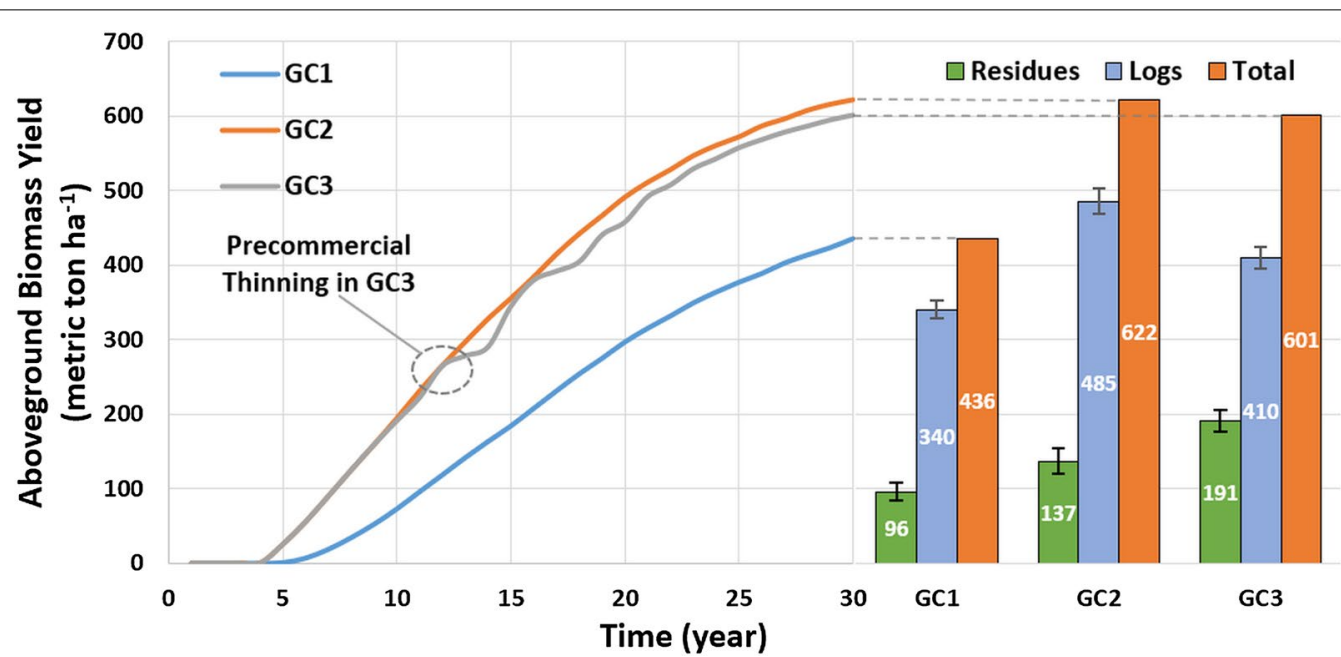

Fig. 1 Pine growth of three cases on 1-ha forest land for a rotation of 30 years 


\section{Life-cycle GWP on 1-MJ biofuel basis}

Figure 2 shows the life-cycle GWP of 1-MJ biofuel produced in two scenarios compared to static method cases (see "Scenario analysis"). Scenario 1 combusts the biochar from fast pyrolysis in the CHP for energy recovery, while Scenario 2 explores the potential implications of utilizing the biochar as a soil amendment (see "Scenario analysis" for detailes). In each scenario, three GCs are presented. The error bars represent the P5-P95 range of the Monte Carlo simulation for the net GWP. The time-based discounted GWP method (100-year analysis timeframe) was applied to quantify the carbon temporal effects of life-cycle $\mathrm{CO}_{2}$ emissions and sequestration in one rotation cycle. For both scenarios in Fig. 2, the carbon sequestered in the residues via $\mathrm{CO}_{2}$ uptake during biomass growth offers significant carbon sequestration credits shown as negative values. Biogenic $\mathrm{CO}_{2}$ emissions during biofuel production are a major emission source. Fossil $\mathrm{CO}_{2}$ emissions from the combined heat and power
(CHP) plant combusting the off-gas from natural gas steam reforming (producing hydrogen) are relatively small compared to the biogenic $\mathrm{CO}_{2}$ emissions from the combustion of fuel gas and biochar. Biofuel combustion (use phase) is another major emission source. The GHG emissions associated with forest operations are minor compared to the other components. The annual carbon emissions in two scenarios are documented in Additional file 1: Section "Carbon Emission Profile". GWPs of conventional fuels are obtained from the Greenhouse Gases, Regulated Emissions, and Energy Use in Technologies (GREET) 2019 [57].

According to Scenario 1 in Fig. 2, first, across the three growth cases $\mathrm{GC} 1-3$, the differences in the static method are insignificant $(<1.5 \%)$ due to two reasons: (1) across $\mathrm{GC} 1-3$, the GHG emissions by forest operations on 1-MJ basis are small (4.3-4.7 $\left.\mathrm{g} \mathrm{CO}_{2} \mathrm{e} \mathrm{MJ}^{-1}\right)$, so the GHG differences brought by different forest management and site productivity are small; (2) the temporal effects
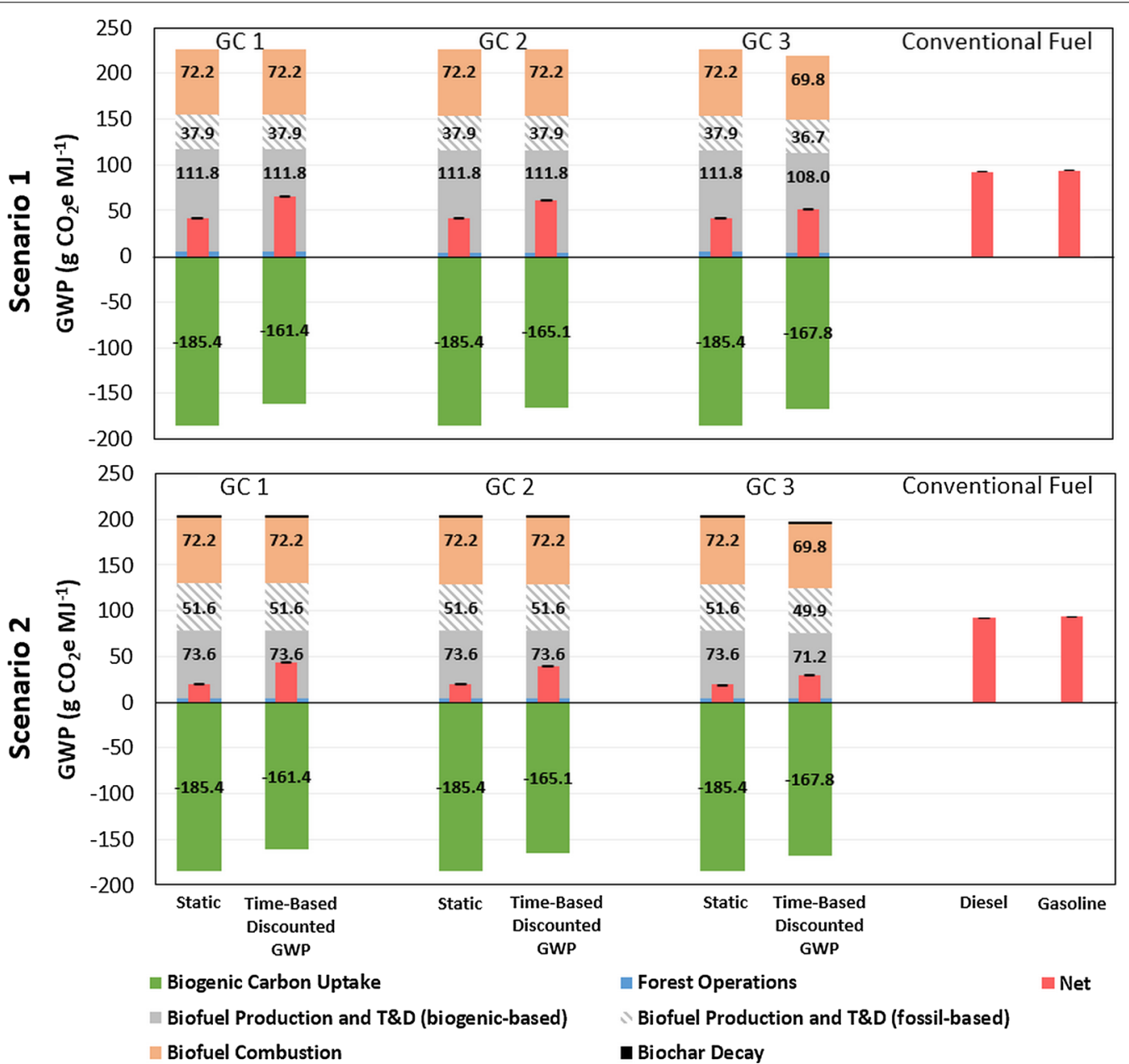

Fig. 2 Life-cycle GWP of 1 MJ biofuel using the time-based discounted GWP method in two scenarios compared to conventional fossil fuels (error bar for P5-P95 of the net GWP): Scenario 1 Energy Recovery and Scenario 2 Biochar Utilization. T\&D: biomass transportation and fuel distribution 
of different carbon emission profiles of growth cases are not considered in the static method, so the temporal features of three different growth cases do not differ. Second, using the time-based discounted GWP method increases the GHG emissions given the assumption that the carbon cycle starts with the collection of the pine residues for conversion to and combustion of biofuels prior to the subsequent carbon uptake during biomass growth in a new rotation. Taking Scenario 1 GC3 as an example, the net time-based discounted GHG emissions are 50.2-51.7 $\mathrm{MJ}^{-1}$ as P5-P95 compared to the static cases 40.3-41.6 $\mathrm{MJ}^{-1}$ as P5-P95. This is mainly due to the differences in biogenic carbon uptake. As the biogenic carbon uptake is sequential and negative in 30 years (see Additional file 1: Fig. S4 and S7), using the time-based discounted GWP method reduces the biogenic carbon uptake and sequestration credits. In GC3, the biogenic carbon uptake in time-based discounted GWP is $-167.8 \mathrm{~g} \mathrm{CO}_{2} \mathrm{e} \mathrm{MJ}^{-1}$ compared to $-185.4 \mathrm{~g} \mathrm{CO}_{2} \mathrm{e} \mathrm{MJ}{ }^{-1}$ in the static method. Third, the different carbon emission profiles in three growth cases also lead to varied GHG results of each component with the time-based discounted GWP method. GC3 biogenic carbon uptake is $-167.8 \mathrm{~g} \mathrm{CO}_{2} \mathrm{e} \mathrm{MJ}{ }^{-1}$ compared to $-161.4 \mathrm{~g} \mathrm{CO}_{2} \mathrm{e}$ $\mathrm{MJ}^{-1}$ in GC1 and -165.1 in GC2. This is determined by the GWP discounting curve with the time-based discounted GWP method (see Additional file 1: Fig. S4) where the value of discounted GWP value decreases in later years of the 100-year analysis timeframe. In GC3, the carbon uptake rate per MJ basis in the first 12 years is much larger than GC1 and GC2 (see Additional file 1: Sect. "Carbon Emission Profile", Fig. S5-S7) due to the precommercial thinning happening in year 12 and felling the trees that are all viewed as residues. Due to the precommercial thinning, 39\% (mean value) of the GC3 residue output occurs in year 12 and $61 \%$ in year 30 (end of the rotation), compared to $100 \%$ of residue output in year 30 in GC1 and GC2. Besides in varying GWP of biogenic carbon uptake, the phenomenon led by different carbon emission profiles is also observed in the varying GWP of biofuel production and biomass transportation and fuel distribution (T\&D), and biofuel combustion in different growth cycles. In GC3, year 1 and year 12 have impulse emissions by biofuel production and T\&D, and biofuel combustion, while GC1 and GC2 have those emissions in year 1. Hence, time-based discounted GWP method discounts the emissions in year 12 of Scenario 1 GC3 and results in lower GWP results in biofuel production and T\&D (144.7 $\left.\left.\mathrm{g} \mathrm{CO}_{2} \mathrm{e} \mathrm{M}\right)^{-1}\right)$, and biofuel combustion $\left(69.8 \mathrm{~g} \mathrm{CO}_{2} \mathrm{e} \mathrm{MJ}{ }^{-1}\right)$. It is noticeable that, in Scenario $1 \mathrm{GC} 1$ and GC2, GHG emissions of biofuel production and T\&D (149.7 $\mathrm{g} \mathrm{CO}_{2} \mathrm{e} \mathrm{MJ}{ }^{-1}$ ) and biofuel combustion $\left(72.2 \mathrm{~g} \mathrm{CO}_{2} \mathrm{e} \mathrm{MJ}{ }^{-1}\right)$ are the same with and without applying the time-based discounted GWP method given the same relative GWP factor, which is 1 , in year 1 (starting year). In the comparison of net GWP among the three GCs in Scenario 1, GC3 has the lowest net GWP $\left(51.0 \mathrm{~g} \mathrm{CO}_{2} \mathrm{e} \mathrm{MJ}{ }^{-1}\right)$ compared to $\mathrm{GC} 1$ and $2\left(65.2 \mathrm{~g} \mathrm{CO}_{2} \mathrm{e}\right.$ $\mathrm{MJ}^{-1}$ for $\mathrm{GC} 1$ and $61.1 \mathrm{~g} \mathrm{CO}_{2} \mathrm{e} \mathrm{MJ}{ }^{-1}$ for GC2) with the time-based discounted GWP method. GC3 has the highest yield of forest residues through precommercial thinning that shifts the carbon temporal profile and leads to higher biogenic carbon uptake value and lower carbon emissions compared to GC1 and GC2, as discussed above. This result indicates the need to co-manage forest management and biorefinery production to minimize the life-cycle carbon intensity of biofuels from a life cycle perspective.

In the comparison of Scenario 2 with Scenario 1, the GWP of biogenic carbon uptake, forest operations, and biofuel combustion are the same in the two scenarios since the only difference is the end-of-life of biochar. This difference only impacts the GWP of biofuel production and T\&D, and biochar decay (black bars in Fig. 2 Scenario 2). Compared to Scenario 1, Scenario 2 has a $16.4 \%$ reduction in the GWP of biofuel production and T\&D across all the growth cases and GWP accounting methods due to the carbon stored in biochar instead of being instantaneous release for energy recovery in Scenario 1. This major reduction leads to the decreased net GWP of Scenario 2. For example, in Scenario $2 \mathrm{GC} 3$, the mean net time-based discounted GWP is $29.6 \mathrm{~g} \mathrm{CO}_{2} \mathrm{e} \mathrm{MJ}{ }^{-1}$ and biofuel production and T\&D (including fossil- and biogenic-based GWP) are $121.1 \mathrm{~g} \mathrm{CO}_{2} \mathrm{e} \mathrm{MJ}^{-1}$ compared to $51.0 \mathrm{~g} \mathrm{CO}_{2} \mathrm{e} \mathrm{MJ}{ }^{-1}$ in Scenario $1 \mathrm{GC} 3$ that biofuel production and T\&D are $144.7 \mathrm{~g} \mathrm{CO}_{2} \mathrm{e} \mathrm{MJ}{ }^{-1}$. The impact of biochar decay on the net GWP of biofuel is minor as $93.5 \%$ of carbon remains in biochar even after 30 years (see Additional file 1: Section "Biochar decay" for details). This result highlights the significant carbon benefits of utilizing biochar from fast pyrolysis biofuel production for soil amendment.

\section{Life-cycle GWP on 1-ha forest land basis}

This study then conducted extended research on the impacts of varied growth cases on the GWP in two scenarios from the 1-ha perspective by using the residues for biofuel production and combustion in GC1-3 with the time-based discounted GWP compared to the static method (Fig. 3). Although the comparative trends in each growth case of two scenarios are similar to GWP in MJ (Fig. 2), the impacts of forest growth on GWP are more significant on a hectare basis, as demonstrated by the larger differences of GWP across the three growth cases. For example, in Scenario 1, the net GWP of GC3 is $99 \%$ 
higher than that of GC1 in the static method, compared to the negligible difference $(<1.5 \%)$ in Fig. 2 . Such indications are valuable for conducting landscape-level LCA studies where the balance and optimization of overall carbon stock and fluxes associated with forest growth and harvest/mortality are usually considered. An interesting observation is that GC3 has the highest GWP on 1-ha basis, followed by GC2 and GC1, which contrasts with the results in Fig. 2 where GC1 has the highest GWP on 1-MJ basis. This can be explained by more biofuel outputs in GC3 (due to more forest residues) that lead to more GHG emissions associated with biofuel supply chain.

\section{Discussion}

This work addressed temporal effects associated with key parameters of forest growth, management, and operations in the pine residue-derived biofuel production via fast pyrolysis. Parametric distributions of key life-cycle inventory data encompassing forest growth, management, and operations are developed based on rigorous literature review and process-based engineering modeling and they are incorporated in a dynamic approach to understand the temporal effects of forest dynamics and all carbon emissions and uptake. The results show that forest management has a significant impact on the life-cycle carbon intensity of biofuels when the carbon

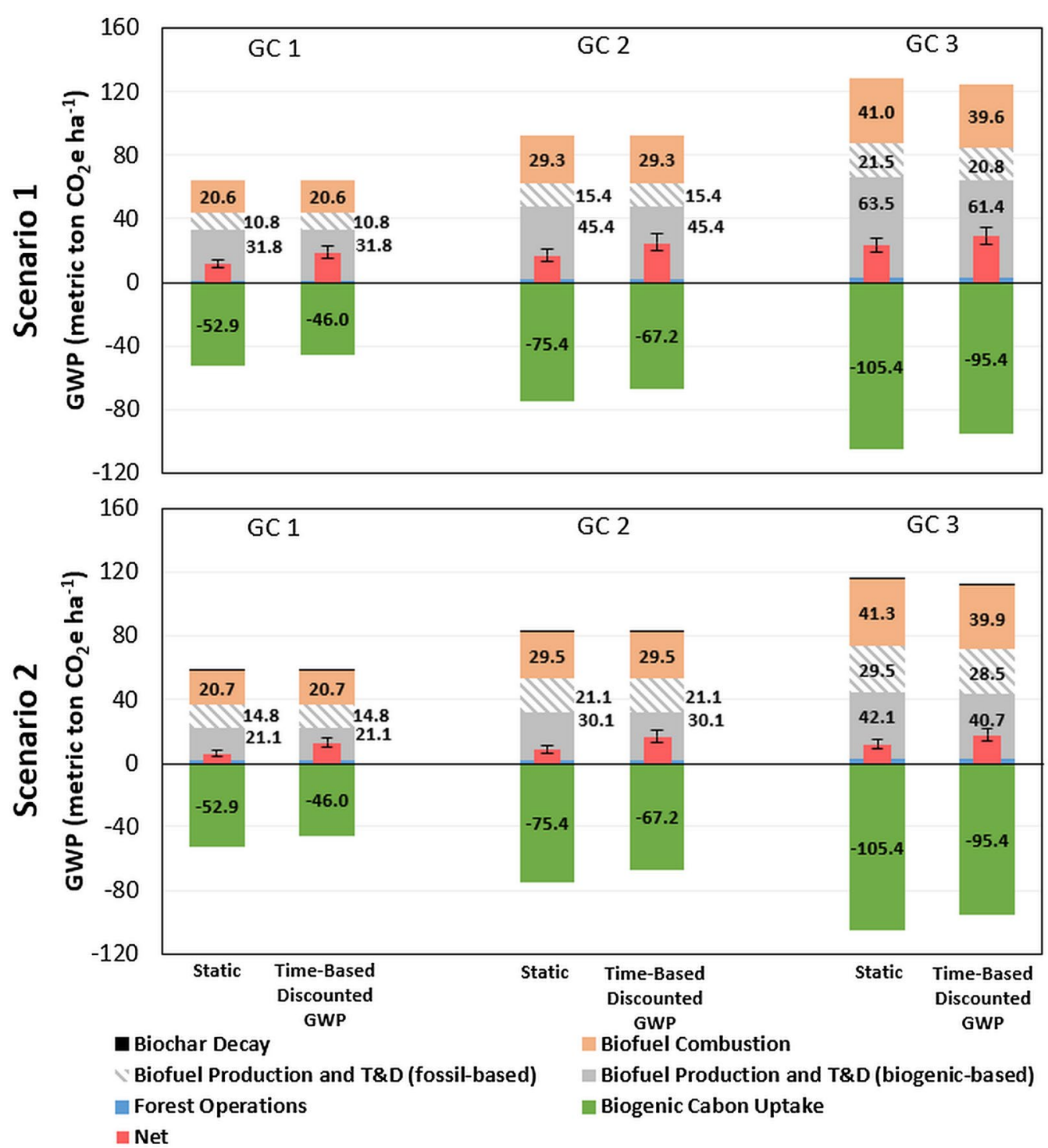

Fig. 3 Life-cycle GWP of 1-ha forest land for 1 rotation in two scenarios (error bar for P5-P95 of the net GWP): Scenario 1 Energy Recovery and Scenario 2 Biochar Utilization. T\&D: biomass transportation and fuel distribution 
temporal effects are considered. Such impact is mainly driven by the variations in biomass yields and carbon take of different forest management strategies, while the variations in energy consumption of forest operation have little impact on the biofuel life-cycle carbon intensity. The variations in quality and chemical composition of the pine residues may impact conversion performance, such as biofuel yield and process energy consumption [58-60], which needs further investigation in this field.

This study evaluated a common carbon neutrality hypothesis in LCA of woody-based bioenergy systems by accounting for the carbon temporal effects associated with carbon emissions and sequestration occurring throughout a 30-year pine growth cycle and biofuel production and end use. Using a time-based discounted GWP method, our results show that the time lag of carbon sequestration during pine growth leads to a discounted climate cooling benefit given a timeframe of 100 years from the present. In other words, the time lag results in a somewhat diminishing GHG emission reduction potential of pine residue-derived biofuels compared to a common assumption of carbon neutrality that treats the impacts of carbon sequestration and emissions as static. Importantly, such results are closely tied to our assumption that utilization of readily available pine residues for biofuel production is the starting point of the analysis, given that the bioenergy industry would likely be motivated to start with what is readily available rather than waiting for the completion of a rotation cycle to produce the needed biomass feedstock. This result further highlights the necessity of taking carbon dynamics into account for decisionmakers and researchers when investigating the climate change mitigation potential of the bioenergy industry. An overlook of the temporal effects of carbon profiles can weaken the understanding to the role of bioenergy in mitigating global warming, especially for the biomass with long growth.

With the consideration of carbon temporal effects, the GWP results of $1 \mathrm{MJ}$ differ across the three growth cases. These three growth cases present varied carbon profiles in biogenic carbon sequestration and GHG emissions due to the variations in site productivity and management strategies (precommercial thinning or not). However, in the static method cases without considering carbon temporal effects, the mean GWP results of $1 \mathrm{MJ}$ biofuel in each scenario have minor differences (i.e., $<1 \%$ for Scenario $1,2 \%-4 \%$ for Scenario 2). The first reason is that the GHG emissions by forest operations on $1 \mathrm{MJ}$ basis are small. Thus, the GHG differences among different growth cases are small. The second reason is that temporal effects of varied carbon profiles are not considered in the static method. This result emphasizes the importance of considering the forest productivity and management strategies in the future bioenergy LCA research when using dynamic carbon analysis.

Switching the view from $1 \mathrm{MJ}$ basis to 1 ha basis exhibits larger impacts of varied growth cases on the GWP results. The understanding of the carbon impacts coming from variations in site productivity and management strategies can further help future research on varied potential pathways of residues (e.g., pile burning, decay) and forest carbon fluxes in soil and aboveground at a larger scale.

In contrast to combusting the biochar from fast pyrolysis for energy recovery in this study, utilizing the biochar as soil amendment leads to the reduction in the net lifecycle GWP of biofuel. This is mainly caused by the high stability and long-term carbon storage ability of biochar. This carbon storage benefit of biochar outweighs the carbon emissions of electricity purchased to fulfill the energy demand in Scenario 2, while in Scenario 1 such energy demand is met by burning biochar that generates instantaneous carbon emissions. This result can inform future biorefinery design when considering alternative uses of biorefinery byproducts, especially those carbonbeneficial applications beyond energy recovery. In addition to soil amendment, biochar has other applications such as water treatment that can be explored in future research [59].

This study is a stand-level analysis that investigates the carbon flows over a cycle of forest operations occurring on a relatively small defined land area (typically up to hundreds of hectares) that have even-aged trees [49, 50, 61]. In contrast, a landscape-level analysis investigates a much larger scale of the forest that are usually unevenaged. Thus, forest carbon pools are averaged across trees in different stages of their growth cycles, resulting in a stable carbon level if no change in forest management [49]. The landscape-level analysis may be more appropriate for bioenergy production from managed forest and sustainable forestry management, which aims to maintain an equilibrium of the overall carbon stock and fluxes associated with forest growth and harvest/mortality. A landscape-level LCA may be more appropriate to address managed forests that tend to offer a constant supply of biomass for bioenergy production, among others. The landscape-level analysis will need additional data like the age-distribution of forest and how different forest management strategies change such distributions.

This study also lays the foundation for future research questions with the woody carbon neutrality issue that should be addressed in a deep de-carbonization context. These questions can include the carbon sequestration effects of underground woody biomass production, alternative carbon fates of woody residues that could be left 
on forest land for decay, and temporal effects of non- $\mathrm{CO}_{2}$ climate forcers, such as $\mathrm{N}_{2} \mathrm{O}$ and $\mathrm{CH}_{4}$ emissions.

\section{Conclusions}

This study conducted a life-cycle carbon analysis to study the GWP of woody-based bioenergy systems by integrating dynamic carbon modeling with parametric process modeling and Monte Carlo simulation which models the uncertainties associated with the forest growth, management, and operations. The temporal effects of carbon emissions and sequestration from a 30-year pine growth cycle and biofuel production and end use were accounted by adopting the dynamic carbon modeling approach. The study shows that the carbon temporal effect, particularly the time lag of carbon sequestration during pine growth, has direct impacts on the carbon intensity of biofuels produced from pine residues from a stand-level pine growth and management point of view. The significance of such impacts is subject to forest management strategies, end-of-life cases of biochar utilization, and the GHG emission profiles over time. This study also shows the potential carbon benefits of utilizing biochar as soil amendment instead of combusting for energy recovery. The variation in biomass productivities in the three pine growth scenarios would result in a noticeable variation in the carbon intensity of the biofuels when the carbon temporal effect is accounted for. However, it has no impact with the conventional carbon neutrality assumption.

To the best of our knowledge, this is the first dynamic carbon analysis study that addresses carbon temporal effects of pine residue-derived biofuel production at a stand-level. It also considers variations in forest operations and productivity and the impacts on biofuel carbon intensity. This analysis highlights the importance of considering the carbon temporal effects of biofuel carbon intensity in a system involving with woody biomass as a feedstock for biofuel production and may warrant further investigation.

\section{Methods}

\section{Functional unit and system boundary}

In this study, a cradle-to-grave carbon analysis was performed in the Greenhouse Gases, Regulated Emissions, and Energy Use in Technologies (GREET) 2019 model [57] following ISO Standard 14040 series [62] to analyze life-cycle energy consumption and GHG emissions of the biofuel production from pine residues via fast pyrolysis followed by hydroprocessing in the southern U.S. The functional unit is $1 \mathrm{MJ}$ of biofuel produced (to be consistent with traditional LCA studies of biofuels). This study investigates the carbon temporal effects of 1 rotation of pine growth (30 years) in a 100-year analysis timeframe.
This study aims to address a key research question, which is, what are the carbon temporal effects of pine residuederived biofuels 100 years from now? The system boundary for woody biomass-derived biofuels (Fig. 4) included biomass production, biomass transportation, biomass conversion, fuel distribution, and end use (or biofuel combustion). Upstream production of chemicals and fuels used in the biomass production, biomass transportation, biomass conversion, and fuel distribution were also included.

It is assumed that the carbon cycle in this analysis starts with pine residues readily available for conversion to biofuels, followed by carbon sequestration during regeneration of pine that takes 30 years, which is likely the only appealing scenario for starting a new, pine residue-to-biofuel biorefinery. This assumption would lead to an initial carbon debt that would take a long time to pay back, generating delayed carbon sequestration benefits that would only partially compensate the initial carbon debt. On the contrary, if a biorefinery would grow pine first and wait for decades to utilize the woody biomass for biofuel production, the initial carbon sequestration benefit would outweigh the carbon debt that would occur years later.

Energy consumption and emissions from forest management operations, biorefinery operations, and biofuel combustion were included in this analysis. Carbon storage in logs, uncollected residues, and residues for biofuel production was modeled on an annual basis by using a forest growth and yield model under three representative pine management cases (e.g., growth rates and thinning). As this study focuses on the cradle-to-grave system boundary, all the dynamic carbon emissions and sequestration were tracked in detail, and the temporal effects are quantified using a discounted GWP method [63]. As this study focuses on the pine plantation forest which is reforested after each rotation, no land use change is involved in this study. Finally, life-cycle inventory (LCI) data of each life-cycle stage were utilized to run GREET's Monte Carlo simulation where the pre-defined and mutually independent probability density functions of the key parameters were tested to understand how the uncertainties and variabilities influenced the environmental impacts and carbon analysis results in different scenarios.

\section{Biomass production}

The energy consumption and GHG emissions in the biomass production stage mainly come from forest operations. In this study, fertilized and thinned loblolly pine plantations (FASTLOB), which is a stand-level growth and yield model [56], was used to simulate a loblolly pine (Pinus taeda L.) plantation and the associated biomass 


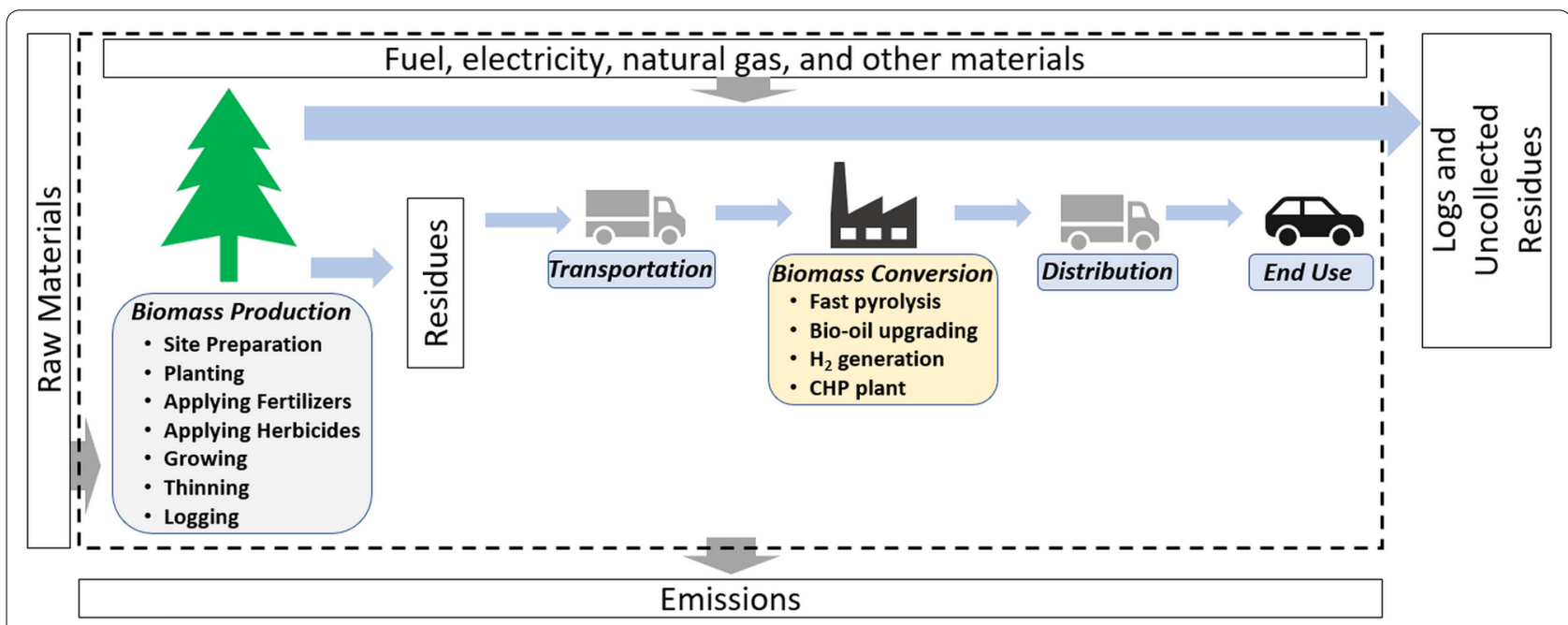

Fig. 4 The system boundary of the carbon analysis

generated during thinning and final harvesting under different forest operation conditions.

\section{Forest operations}

Pine growth and yield simulation includes site preparation (including herbicide application), planting, fertilization, thinning, logging, and chipping (more details available in Additional file 1: Section "Forest operations"). While site preparation, planting, and herbicide application are performed at the beginning of one rotation [64], fertilizers are applied twice during the rotation based on the work by Amateis et al. [65]. At the end of a rotation, all the aboveground trees were cut down, generating logs and residues. Thinning is operated as "a silvicultural treatment that reduces tree density primarily to improve tree growth, to enhance forest health, or for economic reasons" [66-68]. As one widely used type of thinning, precommercial thinning commonly takes place at the early stage of a rotation and usually before trees reach merchantable size [69, 70]. Hence, biomass outputs from precommercial thinning are only residues. The benefits of precommercial thinning include preventing stagnation, increasing the stem volume per tree (in other words, produce logs with larger size), and reducing the risk of southern pine beetles $[68,69,71]$. Logging at the end of one rotation and precommercial thinning in the middle of the rotation are the main sources of pine residues [72]. Logging also generates logs that are the main products of forest operations. Balancing the value of the logs obtained and the cost of precommercial thinning is always a complex issue for landowners and depends on many factors such as the availability of sawmills (determining the logistic cost for logs) or wood products manufacturers for logs of different size and quality (determining the selling prices for logs). One study for pine plantation in the southeastern U.S., more specifically Alabama, indicated that forest landowners were encouraged to practice thinning for bioenergy under favorable biomass and/or timber prices [73]. Therefore, this study included the impacts of precommercial thinning into three GCs detailed in a later section (Section "Pine growth and yield") [74]. Residues collected from thinning and logging were assumed to be chipped onsite and then transported to the biorefinery. Based on the data from the US Department of Agriculture Forest Service for southern softwood, the mass fraction of foliage and branches (residues) were assumed to be $19-25 \%$ of the aboveground live tree mass, the rest of which were stem wood and stem bark (logs) [75]. Hence, the residues consist of two portions, all the biomass outputs of precommercial thinning, and $19-25 \%$ of the biomass outputs of logging. More details of calculating residue amount are available in Additional file 1: Section "Pine growth and yield". Not all residues were collected to minimize the potential environmental impacts (e.g., biological diversity, risk of soil erosion, feedstock characteristics, machinery technology) $[36,76,77]$. The mass fraction of collectible residues for biofuel production was assumed to be $50-70 \%$ with the rest of residues left on forest land $[36,76,77]$. Uncollected residues were not included in the system boundary as shown in Fig. 4. The residues left on the forest land are prone to natural decay which emits GHG [78]. The dynamics of forest residues are complex and could be included in the future analysis as counterfactual scenarios.

The main energy and material requirements of forest operations are diesel fuel for equipment operation and applying the chemicals, e.g., fertilizers and herbicides. 
Table 1 Statistical distribution of parameters with variations in the biomass production models

\begin{tabular}{|c|c|c|c|c|c|}
\hline & Unit & Mean & Minimum $^{b}$ & Maximum $^{b}$ & Distribution \\
\hline Diesel consumption in site preparation [64, 82-84] & $\mathrm{kg} \mathrm{ha}^{-1 \mathrm{a}}$ & 72.11 & 43.65 & 94.59 & Uniform $[43.65,94.59]$ \\
\hline Diesel consumption in thinning (with collecting) $[64,82,84-90]$ & $\mathrm{kg} \mathrm{m}^{-3}$ residues & 1.02 & 0.62 & 1.46 & Uniform $[0.62,1.46]$ \\
\hline Diesel consumption in logging $[64,82,83,85-95]$ & $\mathrm{kg} \mathrm{m}^{-3} \log$ & 1.66 & 0.37 & 3.57 & Normal $N\left(1.40,0.6^{2}\right)$ \\
\hline Collectable pine residue mass fraction $[36,76,77]$ & $\%$ & 60 & 50 & 70 & Uniform $[50,70]$ \\
\hline Mass fraction of residue in the whole tree [75] & $\%$ & 22 & 19 & 25 & Uniform $[19,25]$ \\
\hline
\end{tabular}

a $1 \mathrm{ha}=10,000 \mathrm{~m}^{2}$

b The lower and upper bound values are the lowest and highest data collected from the literature

Table 2 Deterministic parameters used in the biomass production models

\begin{tabular}{|c|c|c|}
\hline & Unit & Value \\
\hline \multicolumn{3}{|l|}{ Parameters for forest operations } \\
\hline Rotation length & Year & 30 \\
\hline Diesel consumption of applying fertilizers and herbicides [64] & $\mathrm{kg} \mathrm{ha}^{-1 \mathrm{a}}$ & 7.5 \\
\hline Diesel consumption of planting [64] & $\mathrm{kg} \mathrm{ha}^{-1}$ & 23.4 \\
\hline Diesel consumption of chipping [96] & $\mathrm{kg} \mathrm{m}^{-3}$ residues & 2.8 \\
\hline Diesel consumption of collecting, piling and burning [83] & $\mathrm{kg} \mathrm{ha}^{-1}$ & 145.4 \\
\hline Nitrogen fertilizer usage [65] & $\mathrm{kg} \mathrm{N} \mathrm{ha}^{-1}$ & 103.1 \\
\hline Phosphorus fertilizer usage [65] & $\mathrm{kgP}_{2} \mathrm{O}_{5} \mathrm{ha}^{-1}$ & 12.8 \\
\hline Herbicide usage [64] & $\mathrm{kg} \mathrm{ha}^{-1}$ & 1.36 \\
\hline \multicolumn{3}{|l|}{ Parameters for biomass outputs } \\
\hline Aboveground live tree moisture content [97] & $\%$ wet & 50 \\
\hline Aboveground live tree wet density $[98,99]$ & $\mathrm{kg} \mathrm{m}^{-3}$ & 930 \\
\hline \multicolumn{3}{|l|}{ Parameters for biomass outputs } \\
\hline Pine residue carbon content [57] & $\%$ & 50.1 \\
\hline Pine residue moisture content [57] & \%wet basis & 45 \\
\hline Pine residue ash content [57] & $\%$ & 0.76 \\
\hline
\end{tabular}

a $1 \mathrm{ha}=10,000 \mathrm{~m}^{2}$

The quantity of each input was collected from the literature and statistically analyzed to identify ranges and characterize distributions (Table 1) for Monte Carlo simulation of the impacts of variations in forest operations (see details in Additional file 1: Section "Probability distribution of key parameters"). When only a few data are available, deterministic values were used (Table 2). The energy and GHG (mainly $\mathrm{CO}_{2}, \mathrm{CH}_{4}$, and $\mathrm{N}_{2} \mathrm{O}$ ) emissions of upstream production of fuels and chemicals used in forest operations were from the GREET 2019 model [57]. Also, fertilizer-induced $\mathrm{N}_{2} \mathrm{O}$ emissions were accounted for [79]. In this study, mass allocation was used to allocate energy consumption and emissions associated with forest operations between the logs and forest residues (Additional file 1: Section "Forest operations") [61, 80], instead of using system expansion and economic allocation. According to the ISO Standard 14041 "The method of avoiding allocation by expanding the system boundaries is only applicable when the alternative method is known. Assumptions about what is actually replaced by the output of the alternative system shall be well documented. If the conditions cannot be met, the procedure of system expansion is not applicable and allocation will be required" [81]. The southern pine logs in this study do not have an alternative system that producing the logs with the same quality and function. The conditions of using system expansion cannot be met in this study due to the lack of alternative systems to produce logs and forest residues.

\section{Pine growth and yield}

To evaluate the effects of varied site conditions and alternative loblolly pine plantation management practices on stand-level growth and yield, three representative GCs were developed for FASTLOB simulations whiling maximizing the yield of the more valuable pulpwood and sawtimber products (Table 3). The three GCs differ in site productivities (measured by the site index that is a widely 
Table 3 Growth case (GC) settings

\begin{tabular}{|c|c|c|c|c|c|}
\hline Growth case & Site index & $\begin{array}{l}\text { Planting density (trees } \\
\mathrm{ha}^{-1} \text { ) }\end{array}$ & $\begin{array}{l}\text { Precommercial } \\
\text { thinning }\end{array}$ & $\begin{array}{l}\text { Residual basal area } \\
\left(\mathrm{m}^{2} \mathrm{ha}^{-1}\right)\end{array}$ & $\begin{array}{l}\text { Fertilization } \\
\text { application time (after } \\
\text { planting) }\end{array}$ \\
\hline GC1 & 60 & 2152 & N/A & N/A & Years 10 and 16 \\
\hline GC2 & 90 & 2152 & N/A & N/A & Years 10 and 16 \\
\hline GC3 & 90 & 2152 & Year 12 & 20.7 & Years 13 and 19 \\
\hline
\end{tabular}

${ }^{\mathrm{a}}$ Residual basal area is the total area of the tree stem at the base after thinning [102]

accepted indicator representing the site quality and the ability of forest land to grow trees $[100,101])$, the timing of the precommercial thinning, and the quantities and schedules of fertilizer application (Additional file 1: Section "Pine growth and yield").

The low and high productive sites were represented by typical site indices of 60 and 90, respectively [97]. In all the cases, a high planting density of 2152 trees ha ${ }^{-1}$ was adopted to more closely reflect forest management aimed at maximizing total biomass growth $[68,73]$. While the exact thinning prescription (schedule and intensity) depends on various factors, including the goals of the landowner, the location of commercial manufacturing infrastructure, rotation age, forest health and vigor, stands are typically thinned when trees start to compete for light, moisture, and nutrition. Such competition can be measured by stand basal area, among other criteria, and it is considered that a stand is in need of thinning when the basal area exceeds 23.0 to $27.6 \mathrm{~m}^{2} \mathrm{ha}^{-1}$ [67]. A thinning prescription aimed at maintaining tree growth and vigor and maximizing sawtimber is usually recommended, where pulpwood is thinned to reduce the basal area to a range between 13.8 and $20.7 \mathrm{~m}^{2} \mathrm{ha}^{-1}$ [67]. Following such recommendation, the thinning intensity was simulated for residual stand basal area of $20.7 \mathrm{~m}^{2} \mathrm{ha}^{-1}$ at age 12 years. Two applications of fertilization were assumed to occur at ages 10 and 16 when the stand was not thinned (GC1 and GC2). However, for GC3, the fertilization was assumed to occur after thinning. The amount of applied nitrogen and phosphorous fertilizers was based on the literature and documented in Table $2[65,73,103$, 104]. Results of the three growth cases are presented in Additional file 1: Table S1, including annual aboveground biomass productivity and removed biomass.

\section{Biomass transportation}

The energy use for the pine residues transported to the biorefinery by trucks was estimated from GREET 2019 [57] where transportation distance 32 miles $(51 \mathrm{~km})$, transportation fuel economy at 0.20 gallon mile ${ }^{-1}$ $\left(0.471 \mathrm{~km}^{-1}\right)$, and truck loading capacity of 20.6 metric tons are assumed.

\section{Biomass conversion}

An Aspen Plus simulation model was developed for the fast pyrolysis biorefinery based on the process model of $\mathrm{Ou}$ et al. [105] and operational data collected from the report [32]. The process flow diagram of the model is shown in Fig. 5. The chips from the forest site are first pretreated to reduce the size and moisture content to $9 \%$ (wet basis) [106]. Size reduction and drying are essential for efficient heat transfer in fast pyrolysis [106, 107]. The heat demand for drying and unit operations was met by the CHP plant inside the biorefinery. The pretreated feedstocks are then sent to fast pyrolysis operated at $500{ }^{\circ} \mathrm{C}$ and $1 \mathrm{~atm}$ pressure in a recirculating fluidized bed reactor. The main products of fast pyrolysis are pyrolytic vapors and solid products such as biochar and sand that are separated by sequential cyclones. Hot sand is sent back to the reactor; biochar with fine particles is sent to $\mathrm{CHP}$ for combusting and heat recovery [108]. The pyrolytic vapors from the fast pyrolysis unit are quenched by a two-stage condenser to separate bio-oil from noncondensable gas (NCG). Part of the NCG is sent back to the pyrolyzer as the fluidizing gas, while the rest is sent to the combustor. In this Aspen Plus biorefinery model, the crude bio-oil is upgraded to hydrocarbon fuels by catalytic upgrading [32]. The hydrocarbon outputs are further distilled in two distillation columns to produce gasolinerange and diesel-range liquids as the final fuel products [32]. The hydrogen needed by the process is supplied by the reforming of natural gas (only fossil fuel used in biorefinery in this study) using the steam from the CHP plant. The off-gas from steam reforming is also sent to the CHP plant. Other studies [32, 33] have assumed that the required hydrogen is derived from the biomass vapors, but the costs and complexities of this alternative relative to the common, mature technology of natural gas reforming, make this alternative less attractive.

As biochar can be used for the soil amendment as a potential carbon sink [109, 110], this study also explores an alternative situation where the biochar is used for soil application instead of being combusted in the CHP plant (see Section "Scenario analysis"). In this situation, if the heat demand cannot be met by NCG and off-gas, natural gas is combusted to provide sufficient heat. For 


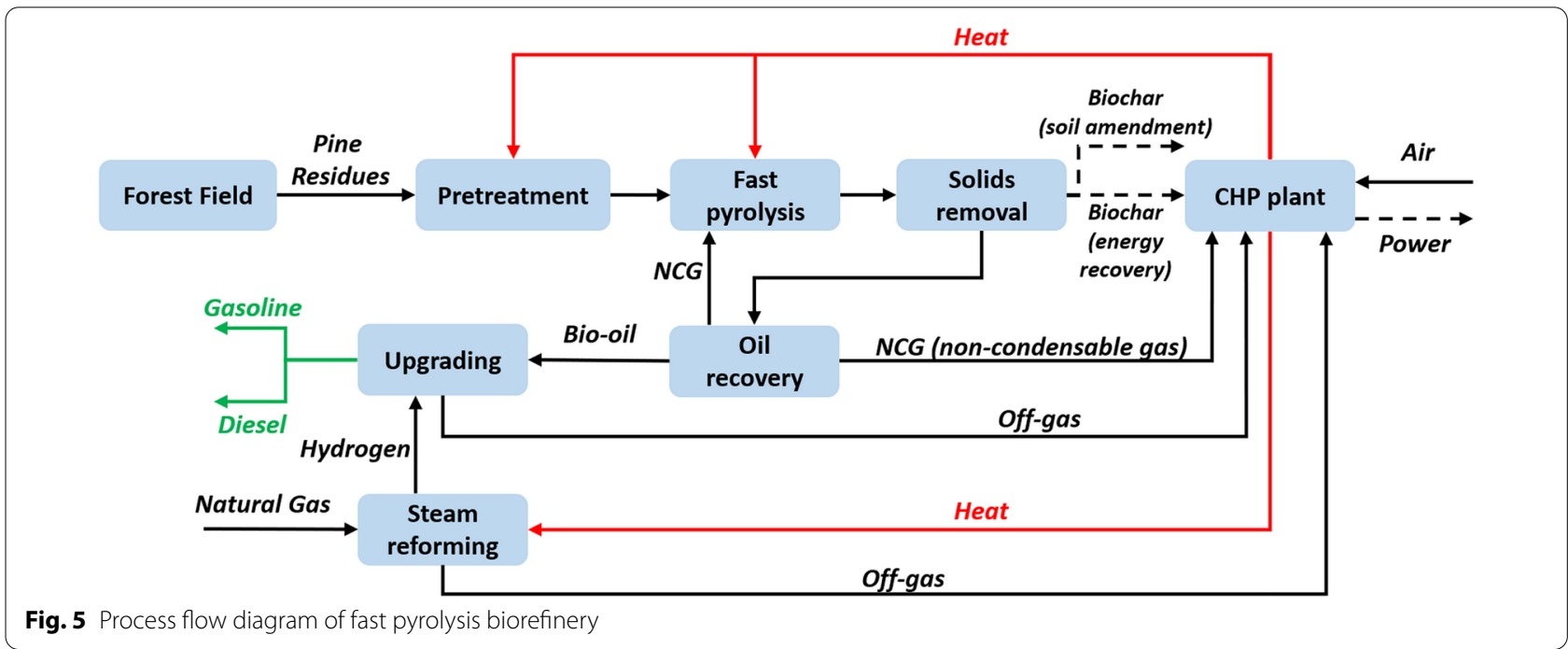

the biochar decay, this study adopted the wide accepted exponential model to account the corresponding GHG emissions after biochar application [111]. The decay rate of fast pyrolysis biochar in soil followed the value given by the Intergovernmental Panel on Climate Change (IPCC) [112]. More details are available in Additional file 1: Section "Biochar decay".

Because the CHP plant has multiple fuel inputs (i.e., biochar, process off-gases, and gas products from oil recovery, upgrading, and steam reforming), the carbon emissions must be separately tracked for biogenic carbon emissions from biomass-based fuels and fossil carbon emissions from off-gases from hydrogen production (originated from natural gas). Hence, the total GHG emissions from the CHP plant are tracked based on the carbon mass of input fuels to record the carbon source information. If the CHP plant generated any surplus electricity, it was assumed to be sold to the grid [33]. System expansion was used for this co-product electricity as a method recommended by ISO Standard 14044 to avoid allocation, this method also has been used in similar biorefineries [113-115]. The surplus electricity is assumed to displace U.S. average electricity mix [57].

\section{Fuel distribution and end use}

Diesel and gasoline products are distributed to the market and used in vehicles. The GHG emission factors of fuel distribution and combustion were collected from GREET 2019 [57].

\section{A time-based discounted GWP method for addressing the carbon temporal effect}

A carbon temporal effect analysis was performed to explore the impacts of carbon sequestration and emissions at different time. In order to evaluate the global warming impacts of the delay between carbon emissions and sequestration, this study estimated cumulative global warming effects based on discounted GWP of carbon emissions and sequestration over time.

A delay between the carbon emissions and sequestration from the start of the utilization of pine residues (generated from the previous pine growth cycle for biofuel production) to the completion of a following 30 -year rotation cycle of pine growth can vary its global warming effects a given timeframe, e.g., 100 years. Such cumulative global warming effects $\left(E_{\text {total }}\right)$ are estimated by the sum of the emissions of carbon emissions in a given year $t, E(t)$, multiplied by the discounted global warming potential (dGWP) of the carbon emissions that start in year $t$ and continue to exert climate impact until 100 years from now, $d G W P(100-t)$ :

$$
E_{\text {total }}=\sum_{t=0}^{N} E(t) \times d G W P(100-t) .
$$

Here, the term, discounted GWP, is defined relative to the traditional static GWP method in which the GWP of $\mathrm{CO}_{2}$ emissions would be considered as 1 , regardless of the timing and time horizon of the carbon emissions and carbon sink. $N$ is the rotation time (30 years for pine in this study). The dGWP of the emissions in year $t$ is the ratio of the absolute global warming potential (AGWP) of the carbon emissions over the subsequent $100-t$ years, $A G W P_{\mathrm{CO} 2}(100-t)$, to that of 
reference $\mathrm{CO}_{2}$ emissions over 100 years from the presence, $A G W P_{C O 2}(100)$ :

$$
d G W P_{C O 2}(t)=\frac{A G W P_{C O 2}(100-t)}{A G W P_{C O 2}(100)} .
$$

AGWP, in $\mathrm{W} \mathrm{m} \mathrm{m}^{-2} \mathrm{~kg}^{-1}$ year $^{-1}$, is the integration of radiative forcing of a climate forcer in a given time horizon. The AGWP of $\mathrm{CO}_{2}$ can be calculated as follows:
GWP of $\mathrm{CH}_{4}$ and $\mathrm{N}_{2} \mathrm{O}$ (after using static GWP-100 characterization factors from IPCC [116]) accounts for only $2 \%$ of the total GHG emissions (in $\mathrm{CO}_{2} \mathrm{e}$ ) in Scenario 1 static method cases (see "Scenario analysis" for scenario analysis details).

To compare the time-based discounted GWP method with current static LCA practice where temporal effects are not considered, this study included a static method

$$
A G W_{C O 2}(t)=1.759 e^{-15}\left[a_{0} t+\sum_{i=1}^{3} a_{i} \tau_{i}\left(1-\exp \left(-\frac{t}{\tau_{i}}\right)\right)\right] \text {, }
$$

where $1.759 e^{-15}$ is the radiative efficiency for $\mathrm{CO}_{2}$ in W $\mathrm{m}^{-2} \mathrm{~kg}^{-1}, \tau_{i}$ are the perturbation time scales for three modes of redistribution of $\mathrm{CO}_{2}$ upon release, $a_{i}$ are the weighting factors for the effect of each perturbation time scale. $\tau_{i}$ and $a_{i}$ are estimated by the average values of a set of climate models [116]. $\left[a_{0} t+\sum_{i=1}^{3} a_{i} \tau_{i}\left(1-\exp \left(-\frac{t}{\tau_{i}}\right)\right)\right]$ can be recognized as the integral result of the IRF of $\mathrm{CO}_{2}$ in the atmosphere [116]. Additional file 1: Fig. S4 shows the dGWP of $\mathrm{CO}_{2}$ emissions occurring in year $t$ from now and last until 100 years from now as estimated by IPCC. We applied this time-based discounted GWP method to quantify the carbon temporal effect of the carbon emissions and sequestration occurring along the supply chain of the pine residues-derived biofuel production within a 30-year rotation cycle. Note that the temporal effects of emissions from other GHGs such as $\mathrm{CH}_{4}$ and $\mathrm{N}_{2} \mathrm{O}$ are not considered given their minimal contributions compared to $\mathrm{CO}_{2}$ emissions. For example, the case that used static GWP conversion factors for 100 years from IPCC [116].

To better understand the temporal carbon profile of three GCs, Table 4 summarizes the timeline of the forest operations in three GCs (details available in Additional file 1: Fig. S5-S7). In this study, as mentioned above, the biofuel production of final harvested residues from the previous rotation in each GC is assumed to happen in year 1 , or at the end of the previous rotation.

\section{Scenario analysis}

In this study, two scenarios were designed to explore the implications of using biochar or for agriculture application, varied forest growth and yield, and carbon accounting methods. Table 5 summarizes the scenario analysis settings of this study. To account for the variabilities, 1000 iterations were run in the Monte Carlo simulation for each case in each scenario.

Table 4 The timeline of activities within one rotation in three GCs

\begin{tabular}{llllll}
\hline Year & $\mathbf{1}$ & $\mathbf{1 0}$ & $\mathbf{1 2}$ & $\mathbf{1 3}$ & $\mathbf{1 6}$ \\
\hline GC1 & $\begin{array}{l}\text { Logging and biofuel production (from the previous rotation); } \\
\text { GC2 }\end{array}$ & Site preparation and planting & Fertilization & Fertilization \\
GC3 & & $\begin{array}{l}\text { Precommercial thinning } \\
\text { and biofuel production }\end{array}$ & Fertilization & Fertilization \\
\hline
\end{tabular}

Table 5 Scenario analysis

\begin{tabular}{llll}
\hline Scenarios & Growth cases & Biochar usage & GWP accounting methods \\
\hline Scenario 1 & GC1-3 & $\begin{array}{l}\text { Combusted in the CHP for } \\
\text { energy recovery }\end{array}$ & Traditional static method; time-based discounted GWP method \\
Scenario 2 & & Soil amendment & \\
\hline
\end{tabular}




\begin{abstract}
Abbreviations
GHG: Greenhouse gas; LCA: Life Cycle Assessment; DOE: Department of Energy; GWP: Global warming potential; IRF: Impulse response function; GC: Growth case; SI: Supplementary information; CHP: Combined heat and power; GREET: Greenhouse Gases, Regulated Emissions, and Energy Use in Technologies; T\&D: Transportation and distribution; LCl: Life-cycle inventory; FASTLOB: Fertilized and thinned loblolly pine plantations; NCG: Non-condensable gas; IPCC: Intergovernmental Panel on Climate Change; dGWP: Discounted global warming potential; AGWP: Absolute global warming potential.
\end{abstract}

\section{Supplementary Information}

The online version contains supplementary material available at https://doi. org/10.1186/s13068-021-02027-4.

Additional file 1. Figure $\mathbf{S 1}$. The process flow chart of pine residue production. Figure S2. The timeline of Growth Case 1 and 2 in one rotation. Figure S3. The timeline of Growth Case 3 in one rotation. Figure S4. Timebased discounted GWP of $\mathrm{CO}_{2}$ for 100 years from the presence. Figure S5. Annual $\mathrm{CO}_{2}$ emissions and sequestration (mean value) of $1 \mathrm{MJ}$ of biofuel produced in Scenario 1 Growth Case 1. Figure $\mathbf{S 6}$. Annual $\mathrm{CO}_{2}$ emissions and sequestration (mean value) of $1 \mathrm{MJ}$ of biofuel produced in Scenario 1 Growth Case 2. Figure S7. Annual $\mathrm{CO}_{2}$ emissions and sequestration (mean value) of $1 \mathrm{MJ}$ of biofuel produced in Scenario 1 Growth Case 3. Figure $\mathbf{8 8}$. Annual $\mathrm{CO}_{2}$ emissions and sequestration (mean value) of $1 \mathrm{MJ}$ of biofuel produced in Scenario 2 Growth Case 1. Figure $\mathbf{5 9}$. Annual $\mathrm{CO}_{2}$ emissions and sequestration (mean value) of $1 \mathrm{MJ}$ of biofuel produced in Scenario 2 Growth Case 2. Figure S10. Annual $\mathrm{CO}_{2}$ emissions and sequestration (mean value) of $1 \mathrm{MJ}$ of biofuel produced in Scenario 2 Growth Case 3. Table S1. Accumulative aboveground biomass data for one rotation (metric ton/ha). Table S2. Key parameter values and distributions based on literature data.

\section{Acknowledgements}

This is a collaborated work from the research team at North Carolina State University, Yale University, and Argonne National Laboratory. We thank the funding support from US Department of Energy, Office of Energy Efficiency \& Renewable Energy (EERE). We also thank the function support from U.S. National Science Foundation.

\section{Authors' contributions}

$\mathrm{KL}$ collected the data, conducted the simulation, and analyzed the data. PN contributed in simulating forest growth and yield. YY, SP, SSK, HC supervised the study. KL, YY, OL, HK, and HC drafted the manuscript. All authors contributed to revising the manuscript. All authors read and approved the final manuscript.

\section{Funding}

The funding support is from US Department of Energy, Office of Energy Efficiency \& Renewable Energy (EERE), prime contract No. DE-AC02-06CH11357, and also the US Department of Energy, Office of Energy Efficiency and Renewable Energy (EERE), under Award Number DE-EE0006639. This work is partially supported by the National Science Foundation under Grant No. (1847182 and 2038439). Any opinions, findings, and conclusions or recommendations expressed in this material are those of the author(s) and do not necessarily reflect the views of the National Science Foundation.

\section{Availability of data and materials}

All data generated or analyzed during the study are included in this published article, the supplementary information, and open-access GREET model.

\section{Declarations}

Ethics approval and consent to participate Not applicable.

\section{Consent for publication}

Not applicable.

\section{Competing interests}

The authors declare that they have no competing interests.

\section{Author details}

'Department of Forest Biomaterials, North Carolina State University, 2820 Faucette Drive, Raleigh, NC 27606, USA. ${ }^{2}$ Systems Assessment Center, Energy Systems Division, Argonne National Laboratory, 9700 South Cass Avenue, Lemont, IL 60439, USA. ${ }^{3}$ USDA Forest Service, Forest Products Laboratory, 1 Gifford Pinchot Drive, Madison, WI 53726, USA. ${ }^{4}$ Center for Industrial Ecology, Yale School of the Environment, Yale University, 380 Edwards Street, New Haven, CT 06511, USA.

Received: 1 July 2020 Accepted: 28 August 2021

Published online: 29 September 2021

\section{References}

1. Adam B, Le Feuvre P. Technology roadmap delivering sustainable bioenergy. Paris: International Energy Agency; 2017.

2. Wang Z, Dunn JB, Han J, Wang MQ. Influence of corn oil recovery on life-cycle greenhouse gas emissions of corn ethanol and corn oil biodiesel. Biotechnol Biofuels. 2015;8:178.

3. Guo M, Li C, Facciotto G, Bergante S, Bhatia R, Comolli R, et al. Bioethanol from poplar clone Imola: an environmentally viable alternative to fossil fuel? Biotechnol Biofuels. 2015;8:134.

4. US EPA. Sources of Greenhouse Gas Emissions; 2018. https://www.epa. gov/ghgemissions/sources-greenhouse-gas-emissions. Accessed 9 Feb 2019.

5. US EPA. Overview for Renewable Fuel Standard; 2019. https://www.epa. gov/renewable-fuel-standard-program/overview-renewable-fuel-stand ard. Accessed 7 Feb 2019

6. Nie Y, Bi X. Life-cycle assessment of transportation biofuels from hydrothermal liquefaction of forest residues in British Columbia. Biotechnol Biofuels. 2018;11:23.

7. Iglesias L, Laca A, Herrero M, Díaz M. A life cycle assessment comparison between centralized and decentralized biodiesel production from raw sunflower oil and waste cooking oils. J Clean Prod. 2012;37:162-71.

8. Hiloidhari M, Baruah DC, Singh A, Kataki S, Medhi K, Kumari S, et al. Emerging role of Geographical Information System (GIS), Life Cycle Assessment (LCA) and spatial LCA (GIS-LCA) in sustainable bioenergy planning. Biores Technol. 2017;242:218-26.

9. Zhang Y, Hu G, Brown RC. Life cycle assessment of the production of hydrogen and transportation fuels from corn stover via fast pyrolysis. Environ Res Lett. 2013;8:025001.

10. Iribarren D, Peters JF, Dufour J. Life cycle assessment of transportation fuels from biomass pyrolysis. Fuel. 2012;97:812-21.

11. Akgul O, Shah N, Papageorgiou LG. An optimisation framework for a hybrid first/second generation bioethanol supply chain. Comput Chem Eng. 2012:42:101-14.

12. Wang C, Jin H, Peng P, Chen J. Thermodynamics and LCA analysis of biomass supercritical water gasification system using external recycle of liquid residual. Renew Energy. 2019;141:1117-26.

13. Wu M, Wu Y, Wang M. Energy and emission benefits of alternative transportation liquid fuels derived from switchgrass: a fuel life cycle assessment. Biotechnol Prog. 2006;22:1012-24.

14. Lardon L, Hélias A, Sialve B, Steyer JP, Bernard O. Life-cycle assessment of biodiesel production from microalgae. Environ Sci Technol. 2009;43:6475-81.

15. Hays TG. The Application of Geographic Information Systems in an Environmental Life Cycle Assessment of a Bioethanol Production System. Master's Thesis. Raleigh, NC, USA: North Carolina State University; 2016.

16. Shirvani T, Yan X, Inderwildi OR, Edwards PP, King DA. Life cycle energy and greenhouse gas analysis for algae-derived biodiesel. Energy Environ Sci. 2011:4:3773-8.

17. Janssen M, Xiros C, Tillman AM. Life cycle impacts of ethanol production from spruce wood chips under high-gravity conditions. Biotechnol Biofuels. 2016;9:53.

18. Wiloso El, Heijungs R, De Snoo GR. LCA of second generation bioethanol: a review and some issues to be resolved for good LCA practice. Renew Sustain Energy Revs. 2012;16:5295-308. 
19. Pierobon F, Eastin IL, Ganguly I. Life cycle assessment of residual lignocellulosic biomass-based jet fuel with activated carbon and lignosulfonate as co-products. Biotechnol Biofuels. 2018;11:139.

20. Roostaei J, Zhang Y. Spatially explicit life cycle assessment: opportunities and challenges of wastewater-based algal biofuels in the United States. Algal Res. 2017;24:395-402.

21. Cherubini F, Bird ND, Cowie A, Jungmeier G, Schlamadinger B, WoessGallasch S. Energy- and greenhouse gas-based LCA of biofuel and bioenergy systems: key issues, ranges and recommendations. Resour Conserv Recy. 2009;53:434-47.

22. Ou X, Zhang X, Chang S, Guo Q. Energy consumption and GHG emissions of six biofuel pathways by LCA in (the) People's Republic of China. Appl Energy. 2009;86:S197-208.

23. Rocha MH, Capaz RS, Lora EE, Nogueira LAH, Leme MM, Renó ML, et al. Life cycle assessment (LCA) for biofuels in Brazilian conditions: a metaanalysis. Renew Sustain Energy Revs. 2014;37:435-59.

24. Sanz Requena JF, Guimaraes AC, Quirós Alpera S, Relea Gangas E, Hernandez-Navarro S, Navas Gracia LM, et al. Life Cycle Assessment (LCA) of the biofuel production process from sunflower oil, rapeseed oil and soybean oil. Fuel Process Technol. 2011;92:190-9.

25. Han J, Elgowainy A, Dunn JB, Wang MQ. Life cycle analysis of fuel production from fast pyrolysis of biomass. Bioresource Technol. 2013;133:421-8.

26. Hsu DD. Life cycle assessment of gasoline and diesel produced via fast pyrolysis and hydroprocessing. Biomass Bioenerg. 2012;45:41-7.

27. Graham RG, Bergougnoum MA, Overend RP. Fast pyrolysis of biomass. J Anal Appl Pyrol. 1984;6:95-135.

28. Dang Q, Yu C, Luo Z. Environmental life cycle assessment of bio-fuel production via fast pyrolysis of corn stover and hydroprocessing. Fuel. 2014;131:36-42

29. Shen D, Jin W, Hu J, Xiao R, Luo K. An overview on fast pyrolysis of the main constituents in lignocellulosic biomass to valued-added chemicals: structures, pathways and interactions. Renew Sustain Energy Revs. 2015;51:761-74

30. Zaimes GG, Soratana K, Harden CL, Landis AE, Khanna V. Biofuels via fast pyrolysis of perennial grasses: a life cycle evaluation of energy consumption and greenhouse gas emissions. Environ Sci Technol. 2015:49:10007-18.

31. Fan J, Kalnes TN, Alward M, Klinger J, Sadehvandi A, Shonnard DR. Life cycle assessment of electricity generation using fast pyrolysis bio-oil. Renew Energy. 2011;36:632-41.

32. Jones S, Meyer P, Snowden-Swan L, Padmaperuma A, Tan E, Dutta A et al. Process design and economics for the conversion of lignocelIulosic biomass to hydrocarbon fuels: Fast pyrolysis and hydrotreating bio-oil pathway. Pacific Northwest National Laboratory, Richland, WA, USA; 2013. https://www.pnnl.gov/main/publications/external/techn ical_reports/PNNL-23053.pdf. Accessed 18 Feb 2019.

33. Dutta A, Sahir A, Tan E, Humbird D, Snowden-swan L, Meyer P, et al. Process design and economics for the conversion of lignocellulosic biomass to hydrocarbon fuels thermochemical research pathways with in situ and ex situ upgrading of fast pyrolysis vapors. National Renewable Energy Laboratory, Golden, CO, USA; 2015. https://www.nrel.gov/ docs/fy15osti/62455.pdf. Accessed 18 Feb 2019.

34. Perlack RD, Eaton LM, Turhollow AFJ, Langholtz MH, Brandt CC, Downing ME, et al. U.S. Billion-ton update: biomass supply for a bioenergy and bioproducts industry. Oak Ridge National Laboratory, Oak Ridge, TN, USA; 2011. https://info.ornl.gov/sites/publications/files/Pub31057. pdf. Accessed 18 Mar 2019.

35. Lan K, Ou L, Park S, Kelley SS, Yao Y. Life cycle analysis of decentralized preprocessing systems for fast pyrolysis biorefineries with blended feedstocks in the southeastern United States. Energy Technol. 2019;8:1900850.

36. Riffell S, Verschuyl J, Miller D, Wigley TB. Biofuel harvests, coarse woody debris, and biodiversity - a meta-analysis. Forest Ecol Manag. 2011;261:878-87.

37. Kenney KL, Cafferty KG, Jacobson JJ, Bonner IJ, Gresham G, Hess JR, et al. Feedstock supply system design and economics for conversion of lignocellulosic biomass to hydrocarbon fuels conversion pathway: fast pyrolysis and hydrotreating bio-oil pathway "The 2017 Design Case".
Idaho National Laboratory, Idaho Falls, ID, USA; 2014. https://inldigital library.inl.gov/sites/sti/sti/6038147.pdf. Accessed 11 Apr 2019.

38. Sahoo K, Bilek E, Bergman R, Mani S. Techno-economic analysis of producing solid biofuels and biochar from forest residues using portable systems. Appl Energy. 2019;235:578-90.

39. Han HS, Jacobson A, Bilek EM, Sessions J. Waste to wisdom: utilizing forest residues for the production of bioenergy and biobased products. Appl Eng Agric. 2018;34:5-10.

40. Cherubini F, Peters GP, Berntsen T, Strømman AH, Hertwich E. $\mathrm{CO}_{2}$ emissions from biomass combustion for bioenergy : atmospheric decay and contribution to global warming. GCB Bioenergy. 2011;3:413-26.

41. Levasseur A, Lesage P, Margni M, Deschěnes L, Samson R. Considering time in LCA: dynamic LCA and its application to global warming impact assessments. Environ Sci Tech. 2010;44:3169-74.

42. Albers A, Collet P, Lorne D, Benoist A, Hélias A. Coupling partial-equilibrium and dynamic biogenic carbon models to assess future transport scenarios in France. Appl Energy. 2019;239:316-30.

43. Joos F, Bruno M. Pulse response functions are cost-efficient tools to model the link between carbon emissions, atmospheric CO2 and global warming. Phys Chem Earth. 1997;21:471-6.

44. Faraca G, Tonini D, Astrup TF. Dynamic accounting of greenhouse gas emissions from cascading utilisation of wood waste. Sci Total Environ. 2019;651:2689-700.

45. Yang J, Chen B. Global warming impact assessment of a crop residue gasification project-A dynamic LCA perspective. Appl Energy. 2014;122:269-79.

46. Daystar J, Venditti R, Kelley SS. Dynamic greenhouse gas accounting for cellulosic biofuels: implications of time based methodology decisions. Int J Life Cycle Assess. 2017;22:812-26.

47. Bright RM, Cherubini F, Strømman AH. Climate impacts of bioenergy: inclusion of carbon cycle and albedo dynamics in life cycle impact assessment. Environ Impact Assess Rev. 2012;37:2-11.

48. Sterman JD, Siegel L, Rooney-Varga JN. Does replacing coal with wood lower CO 2 emissions? Dynamic lifecycle analysis of wood bioenergy. Environ Res Lett. 2018:13:015007.

49. Jonker JGG, Junginger M, Faaij A. Carbon payback period and carbon offset parity point of wood pellet production in the South-eastern United States. GCB Bioenergy. 2014;4:371-89.

50. Ter-Mikaelian MT, Colombo SJ, Chen J. The burning question: does forest bioenergy reduce carbon emissions? A review of common misconceptions about forest carbon accounting. J Forest. 2014;113:57-68.

51. Rolls W, Forster PM. Quantifying forest growth uncertainty on carbon payback times in a simple biomass carbon model. Environ Res Commun. 2020;2:045001.

52. Nabuurs GJ, Arets EJMM, Schelhaas MJ. European forests show no carbon debt, only a long parity effect. For Policy Econ. 2017;75:120-5.

53. Pingoud K, Ekholm T, Savolainen I. Global warming potential factors and warming payback time as climate indicators of forest biomass use. Mitig Adapt Strateg Glob Chang. 2012;17:369-86.

54. Lippke B, Oneil E, Harrison R, Skog K, Gustavsson L, Sathre R. Life cycle impacts of forest management and wood utilization on carbon mitigation: knowns and unknowns. Carbon Manag. 2011;2:303-33.

55. Helin T, Sokka L, Soimakallio S, Pingoud K, Pajula T. Approaches for inclusion of forest carbon cycle in life cycle assessment-a review. GCB Bioenergy. 2013;5:475-86.

56. Amateis RL, Burkhart HE, Lee Allen H, Montes C. FASTLOB (A Stand-Level Growth and Yield Model for Fertilized and Thinned Loblolly Pine Plantations); 2001. https://fmrc.frec.vt.edu/content/dam/fmrc_frec_vt_edu/ documents/fastlob.pdf. Accessed 11 May 2020.

57. The greenhouse gases, regulated emissions, and energy use in technologies (GREET) model. Argonne National Laboratory, Lemont, IL, USA; 2019

58. Ou L, Cai H. Dynamic life-cycle analysis of fast pyrolysis biorefineries: impacts of feedstock moisture content and particle size. ACS Sustain Chem Eng. 2020;8:6211-21.

59. Liao M, Kelley S, Yao Y. Generating energy and greenhouse gas inventory data of activated carbon production using machine learning and kinetic based process simulation. ACS Sustain Chem Eng. 2020;8:1252-61. 
60. Lan K, Park S, Kelley SS, English BC, Yu TE, Larson J, et al. Impacts of uncertain feedstock quality on the economic feasibility of fast pyrolysis biorefineries with blended feedstocks and decentralized preprocessing sites in the southeastern United States. GCB Bioenergy. 2020;12:1014-29.

61. Han J, Canter CE, Cai H, Wang M, Qin Z, Dunn JB. Carbon dynamics for biofuels produced from woody feedstocks. Argonne National Laboratory, Lemont, IL USA; 2018. https://greet.es.anl.gov/publication-woody_ Ica. Accessed 11 Jan 2020.

62. ISO: ISO 14040:2006, Environmental management - Life cycle assessment-principles and framework; 2006. https://www.iso.org/standard/ 37456.html. Accessed 11 Apr 2020.

63. Smith JE, Heath LS, Skog KE, Birdsey RA. Methods for calculating forest ecosystem and harvested carbon with standard estimates for forest types of the United States. USDA Forest Service, Northeastern Research Station, Newtown Square, PA, USA; 2006. https://www.fs.usda.gov/trees earch/pubs/22954. Accessed 11 Apr 2020.

64. Markewitz D. Fossil fuel carbon emissions from silviculture: impacts on net carbon sequestration in forests. Forest Ecol Manag. 2006;236:153-61.

65. Amateis RL, Liu J, Ducey MJ, Lee AH. Modeling response to midrotation nitrogen and phosphorus fertilization in loblolly pine plantations. South J Appl Forestry. 2000;24:207-12.

66. Verschuyl J, Riffell S, Miller D, Wigley TB. Biodiversity response to intensive biomass production from forest thinning in North American forests - a meta-analysis. Forest Ecol Manag. 2011;261:221-32.

67. Dickens ED, Moorhead DJ. A guide to thinning pine plantations. University of Georgia; 2015. https://bugwoodcloud.org/bugwood/productivi ty/pdfs/Guide_thinning_pine_plantations.pdf. Accessed 19 May 2020.

68. Nebeker TE, Hodges JD, Karr BK, Moehring DM. Thinning practices in southern pines-with pest management recommendations. USDA Forest Service; 1985. http://ageconsearch.umn.edu/bitstream/156818/2/ tb1703.pdf. Accessed 19 May 2019.

69. Mann WF, Lohrey RE. Precommercial thinning of southern pines. J Forest. 1974;72:557-60.

70. Blakeslee GM, Jokela EJ, Hollis CH, Wilson DS, Lante WD, Allen JE. Pitch canker in young loblolly pines: influence of precommercial thinning and fertilization on disease incidence and severity. South J Appl Forestry. 1999;23:139-43.

71. Watson AC, Sullivan J, Amacher GS, Asaro C. Cost sharing for pre-commercial thinning in southern pine plantations: willingness to participate in Virginia's pine bark beetle prevention program. Forest Policy Econ. 2013;34:65-72.

72. Edmunds CW, Reyes Molina EA, André N, Hamilton C, Park S, Fasina $\mathrm{O}$, et al. Blended feedstocks for thermochemical conversion: biomass characterization and bio-oil production from switchgrass-pine residues blends. Front Energy Res. 2018;6:79.

73. Gallagher TV, Kantavichai R, Teeter LD. An economic analysis of incorporating biomass thinning into loblolly pine plantations in Alabama. Open J Forestry. 2017;7:172-87.

74. Mederski P, Venanzi R, Bembenek M, Karaszewski Z, Rosińska M, Pilarek $Z$, et al. Designing thinning operations in 2nd age class pine standseconomic and environmental implications. Forests. 2018;9:335.

75. Jenkins JC, Chojnacky DC, Heath LS, Birdsey RA. National-scale biomass estimators for united states tree species. Forest Sci. 2003;49:12-35.

76. Langholtz MH, Stokes BJ, Eaton LM. 2016 Billion-ton report: advancing domestic resources for a thriving bioeconomy, vol 1: economic availability of feedstocks. Oak Ridge National Laboratory, Oak Ridge, TN, USA; 2016. https://www.energy.gov/sites/prod/files/2016/12/f34/2016_ billion_ton_report_12.2.16.pdf. Accessed 18 May 2020.

77. Fritts SR, Moorman CE, Hazel DW, Jackson BD. Biomass Harvesting Guidelines affect downed woody debris retention. Biomass Bioenerg. 2014;70:382-91.

78. Lan K, Kelley SS, Nepal P, Yao Y. Dynamic life cycle carbon and energy analysis for cross-laminated timber in the Southeastern United States. Environ Res Lett. 2020;15(12):124036

79. Wang M, Han J, Dunn JB, Cai H. Well-to-wheels energy use and greenhouse gas emissions of ethanol from corn, sugarcane and cellulosic biomass for US use. Environ Res Lett. 2012;7:045905.

80. Daystar J, Reeb C, Gonzalez R, Venditti R, Kelley SS. Environmental life cycle impacts of cellulosic ethanol in the Southern U.S. produced from loblolly pine, eucalyptus, unmanaged hardwoods, forest residues, and switchgrass using a thermochemical conversion pathway. Fuel Processing Technol. 2015;138:164-74.

81. ISO. ISO 14041: 1998 Environmental management — Life cycle assessment-goal and scope definition and inventory analysis; 1998. https:// www.iso.org/standard/23152.html. Accessed 11 Apr 2020.

82. Dwivedi P, Alavalapati JR, Susaeta A, Stainback A. Impact of carbon value on the profitability of slash pine plantations in the southern United States: an integrated life cycle and Faustmann analysis. Can J Forest Res. 2009;39:990-1000.

83. Oneil EE, Johnson LR, Lippke BR, McCarter JB, McDill ME, Roth PA, et al. Life-cycle impacts of inland Northwest and Northeast/North central forest resources. Wood Fiber Sci. 2010;42:29-51.

84. Kilpeläinen A, Alam A, Strandman H, Kellomäki S. Life cycle assessment tool for estimating net $\mathrm{CO}_{2}$ exchange of forest production. GCB Bioenergy. 2011;3:461-71.

85. Johnson L, Lippke B, Oneil E. Modeling biomass collection and woods processing life-cycle analysis. Forest Product J. 2012;62:258-72.

86. Karjalainen T. Greenhouse gas emissions from the use of primary energy in forest operations and long-distance transportation of timber in Finland. Forestry. 1996;69:215-28.

87. Lindholm E. Energy Use and Environmental Impact of Roundwood and Forest Fuel Production in Sweden. Dissertation. Uppsala: Swedish University of Agricultural Sciences Energy; 2010.

88. Alam A, Kilpeläinen A, Kellomäki S. Impacts of initial stand density and thinning regimes on energy wood production and management-related $\mathrm{CO}_{2}$ emissions in boreal ecosystems. Eur J Forest Res. 2012;131:655-67.

89. Whittaker C, Mortimer N, Murphy R, Matthews R. Energy and greenhouse gas balance of the use of forest residues for bioenergy production in the UK. Biomass Bioenerg. 2011;35:4581-94.

90. González-García S, Berg S, Feijoo G, Moreira MT. Environmental impacts of forest production and supply of pulpwood: Spanish and Swedish case studies. Int J Life Cycle Assess. 2009;14:340-53.

91. Karjalainen T, Kellomäki S, Pussinen A. Role of wood-based products in absorbing atmospheric carbon. Silva Fennica. 1994;28:67-80.

92. Klvac R, Skoupy A. Characteristic fuel consumption and exhaust emissions in fully mechanized logging operations. J Forest Res. 2009;14:328-34.

93. Athanassiadis D, Lidestav G, Wästerlund I. Fuel, hydraulic oil and lubricant consumption in Swedish mechanized harvesting operations, 1996. J Forest Eng. 1999;10:59-66.

94. Saud P, Wang J, Lin W, Sharma BD, Hartley DS. A life cycle analysis of forest carbon balance and carbon emissions of timber harvesting in West Virginia. Wood Fiber Sci. 2013;45:250-67.

95. McNamee P, Adams PW, McManus MC, Dooley B, Darvell LI, Williams A, et al. An assessment of the torrefaction of North American pine and life cycle greenhouse gas emissions. Energy Convers Manag. 2016;113:177-88.

96. McEwan A, Brink M, Spinelli R. Efficiency of different machine layouts for chain flail delimbing. Debarking Chipping For. 2019;10:126.

97. Schultz RP. Loblolly pine: the ecology and culture of loblolly pine (Pinus taeda L.). USDA Forest Service, Washington D.C., USA; 1997. https:// www.srs.fs.usda.gov/pubs/734. Accessed 11 Apr 2020.

98. Patterson DW, Doruska PF, Posey T. Weight and bulk density of loblolly pine plywood logs in southeast Arkansas. Forest Prod J. 2004;54:145-9.

99. Patterson HT, Clark Al. Bulk density of southern pine logs. Forest Prod J. 1988;38:36-40

100. MacFarlane DW, Green EJ, Burkhart HE. Population density influences assessment and application of site index. Can J Forest Res. 2000;30:1472-5.90.

101. Doolittle WT. Site index comparisons for several forest species in the southern Appalachians. Soil Sci Soc Am J. 1958;22:455-8.

102. Hudak AT, Crookston NL, Evans JS, Falkowski MJ, Smith AM, Gessler PE, et al. Regression modeling and mapping of coniferous forest basal area and tree density from discrete-return lidar and multispectral satellite data. Can J Remote Sens. 2006;32:126-38.

103. Cunningham K, Barry JE, Walkingstick T. Managing Loblolly Pine Stands-from A to Z. University of Arkansas. 2008. https://www.uaex. edu/publications/PDF/FSA-5023.pdf. Accessed 19 Jun 2019. 
104. Moorhead DJ, Dickens ED. Fertilizing pine plantations: a county Agent's guide for making fertilization recommendations. University of Georgia; 2002. https://bugwoodcloud.org/resource/files/14828.pdf. Accessed 19 Jun 2019

105. Ou L, Kim H, Kelley S, Park S. Impacts of feedstock properties on the process economics of fast-pyrolysis biorefineries. Biofuel Bioprod Bior. 2018;12:442-52.

106. Ringer M, Putsche V, Scahill J. Large-scale pyrolysis oil production: a technology assessment and economic analysis. National Renewable Energy Laboratory, Golden, CO, USA; 2006. https://www.nrel.gov/docs/ fy07osti/37779.pdf. Accessed 18 Feb 2019.

107. Bridgwater AV, Czernik S, Piskorz J. An overview of fast pyrolysis of biomass. Org Geochem. 1999:30:1479-93.

108. Bridgwater AV, Peacocke GVC. Fast pyrolysis processes for biomass. Renew Sustain Energy Revs. 2000;4:1-73.

109. de la Rosa JM, Rosado M, Paneque M, Miller AZ, Knicker H. Effects of aging under field conditions on biochar structure and composition: implications for biochar stability in soils. Sci Total Environ. 2018;613-614:969-76.

110. Mchenry MP. Agriculture, Ecosystems and Environment Agricultural bio-char production, renewable energy generation and farm carbon sequestration in Western Australia: certainty, uncertainty and risk. Agr Ecosyst Environ. 2009;129:1-7.

111. Lehmann J, Joseph S, editors. Biochar for environmental management: science, technology and implementation. New York: Routledge; 2015.
112. IPCC. 2019 Refinement to the 2006 IPCC Guidelines for National Greenhouse Gas Inventories. Buendia EC, Tanabe K, Kranjc A, Baasansuren J, Fukuda M, Ngarize S, et al, eds. Switzerland: IPCC; 2019. https:// www.ipcc.ch/site/assets/uploads/2019/12/19R_V0_01_Overview.pdf. Accessed 18 Jan 2021.

113. Kim S, Dale BE, Jin M, Thelen KD, Zhang $X$, Meier $P$, et al. Integration in a depot-based decentralized biorefinery system: corn stover-based cellulosic biofuel. GCB Bioenergy. 2019;11:871-82.

114. Winjobi O, Zhou W, Kulas D, Nowicki J, Shonnard DR. Production of hydrocarbon fuel using two-step torrefaction and fast pyrolysis of pine. Part 2: life-cycle carbon footprint. ACS Sustain Chem Eng. 2017:5:4541-51.

115. ISO. ISO 14044: 2006 Environmental management-life cycle assessment-requirements and guidelines; 2006. https://www.iso.org/stand ard/38498.html. Accessed 11 Apr 2020.

116. IPCC. Climate Change 2007: The physical science basis. Contribution of Working Group I to the Fourth Assessment Report of the Intergovernmental Panel on Climate Change. Solomon S, Qin D, Manning M, Chen Z, Marquis M, Averyt KB, et al., editors. Cambridge, United Kingdom and New York, NY, USA: Cambridge University Press; 2007.

\section{Publisher's Note}

Springer Nature remains neutral with regard to jurisdictional claims in published maps and institutional affiliations.
Ready to submit your research? Choose BMC and benefit from:

- fast, convenient online submission

- thorough peer review by experienced researchers in your field

- rapid publication on acceptance

- support for research data, including large and complex data types

- gold Open Access which fosters wider collaboration and increased citations

- maximum visibility for your research: over 100M website views per year

At BMC, research is always in progress.

Learn more biomedcentral.com/submissions 